\title{
The Journal of EUROCALL
}

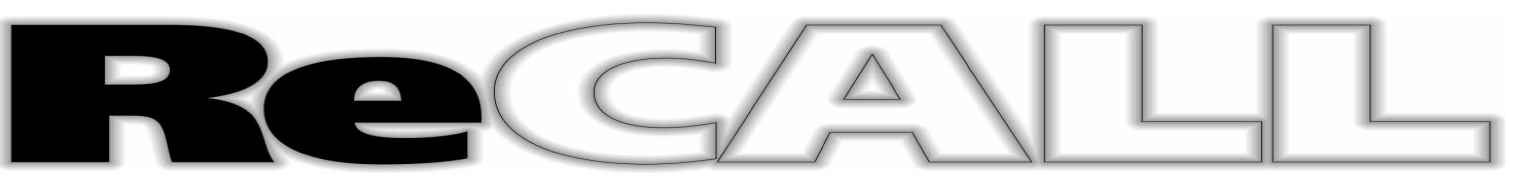

SEPTEMBER 2015

$V O L U M E \quad 27$

An international journal on technologies and language learning 


\section{RECALL \\ Editors \\ Françoise Blin, Dublin City University, Ireland \\ Alex Boulton, University of Lorraine, France \\ Reviews Editor \\ Liam Murray, University of Limerick, Ireland}

Journal Administrator

Sylvie Thouësny

David Barr, University of Ulster, UK

Angela Chambers, University of Limerick, Ireland

Thierry Chanier, Université Blaise Pascal, France

Frederik Cornillie, University of Leuven, Belgium

Françoise Demaizière, Université Paris 7, France

Melinda Dooly, Universitat Autònoma de Barcelona, Spain

Robert Fischer, Texas State University, USA

John Gillespie, University of Ulster, UK

Ana Gimeno-Sanz, Universidad Politécnica de Valencia,

Spain

Nicolas Guichon, Université de Lyon 2, France

Regine Hampel, The Open University, UK

Mirjam Hauck, The Open University, UK

Trude Heift, Simon Fraser University, Canada

Phil Hubbard, Stanford University, USA

Andrea Kárpáti, Eötvös Loránd University, Hungary

Agnes Kukulska-Hulme, The Open University, UK

Marie-Noëlle Lamy, The Open University, UK

\section{Editorial Board}

Michael Levy, The University of Queensland, Australia

David Little, University of Dublin (emeritus), Trinity College,

Dublin 2, Ireland

François Mangenot, Université Stendhal, France

Vera Lúcia Menezes, Universidade Federal de Minas Gerais,

Brazil

Detmar Meurers, Universität Tübingen, Germany

Robert O'Dowd, The University of León, Spain

Sue K. Otto, University of Iowa, USA

Mathias Schulze, University of Waterloo, Canada

Glenn Stockwell, Waseda University, Tokyo, Japan

Peppi Taalas, University of Jyväskylä, Finland

Maija Tammelin, Consultant, Aalto University School

of Business, Finland

Steven L. Thorne, Portland State University,

USA \& University of Groningen, The Netherlands

Cornelia Tschichold, Swansea University,

UK

\section{Subscriptions}

ReCALL (ISSN 0958-3440; electronic ISSN 1474-0109) is published three times a year in January, May and September. Three parts form a volume. The subscription price (excluding VAT and sales tax) of volume 27 (2015) (which includes postage) is $£ 208$ net (US\$358 in the USA, Canada and Mexico) for institutions print and electronic, institutions electronic only is $£ 169 / \$ 294$; $£ 54$ (US\$91 in the USA, Canada and Mexico) for individuals ordering direct from the publisher and certifying that the journal is for their own personal use. Single parts are $£ 76$ (US\$131 in the USA, Canada and Mexico) plus postage. Special reduced rates apply for members of AILA, BAAL, TESOL, and IATEFL. Please enquire at journals@ cambridge.org

Orders, which must be accompanied by payment, may be sent to a bookseller, subscription agent or direct to the publisher: Cambridge University Press, Journals Fulfillment Department, UPH, Shaftesbury Road, Cambridge CB2 8BS, UK; or in the USA, Canada and Mexico: Cambridge University Press, 100 Brook Hill Drive, West Nyack, New York, NY 10994-2133, USA. EU subscribers who are not registered for VAT should add VAT at their country's rate. VAT registered subscribers should provide their VAT registration number. Japanese prices for institutions are available from Kinokunia Company Ltd, PO Box 55, Chitose, Tokyo 156, Japan.

Prices include delivery by air where appropriate, periodicals postage paid at New York, NY, and at additional mailing offices. POSTMASTER: send address changes in the USA, Canada and Mexico to: ReCALL, Cambridge University Press, 100 Brook Hill Drive, West Nyack, New York, NY 10994-2133, USA.

\section{Copying}

This journal is registered with the Copyright Clearance Center, 222 Rosewood Drive, Danvers, MA 01923, USA. Organizations in the USA who are registered with CCC may therefore copy material (beyond the limits permitted by sections 107 and 108 of U.S. Copyright law) subject to payment to CCC of the per-copy fee of $\$ 12.00$. This consent does not extend to multiple copying for promotional or commercial purposes. Code 0958-3440/2012.

ISI Tear Sheet Service, 3501 Market Street, Philadelphia, PA 19104, USA, is authorised to supply single copies of separate articles for private use only.

Organisations authorised by the Copyright Licensing Agency may also copy material subject to the usual conditions.

For all other use, permission should be sought from Cambridge or from the American Branch of Cambridge University Press.

\section{Abstracting and indexing services}

This journal is indexed in ERIC (Education Resources Information Center); British Education Index; EBSCOhost databases: Academic Search Complete, Academic Search Premier, Education Research Index and Education Research Complete; Educational Research Abstracts Online; Educational Technology Abstracts; ERIH (European Reference Index for the Humanities); Pedagogical and Educational Research; Linguistics Abstracts Online; Linguistics and Language Behaviour Abstracts; MLA International Bibliography; Psychological Abstracts; PsycINFO, PsychLIT and Social Science Citation Index.

\section{Internet access}

This journal is included in the Cambridge Journals Online service which can be found at www.journals.cambridge.org/rec. For further information on other Press titles access www.journals.cambridge.org

The publisher has no responsibility for the persistence or accuracy of URLs for external or third-party internet websites referred to in this journal, and does not guarantee that any content on such websites is, or will remain, accurate or appropriate. All URLs were correct at the time at which authors' manuscripts were submitted for publication. 